\title{
Victimization, Empathy, and Breaking the Cycles of Violence in Israel and Palestine
}

\author{
Franke Wilmer \\ Montana State University, Bozeman, USA
}

\begin{abstract}
Victimization narratives arise out of the experience of historical and ongoing injury, and often intersect or, in part, constitute identity narratives. Unless transformed through reconciliation, these narratives can be used to mobilize violent behavior aimed at restoring justice or preventing further victimization. Victimization narratives arise from lived experiences, whether by contemporary generations, or through intergenerational narratives, charging the present generation with the task of ending present or preventing future injury. Those experiences, however, can be mythologized or distorted, particularly when appropriated in support of an ideological agenda. Cycles of violence, therefore, cannot be ended in a sustainable manner unless victimization narratives are transformed and cycles of violence disrupted. This is the work of conflict transformation and sustainable post-conflict democratic institution-building. Since the present global political landscape is made up of thousands of identity or communal groups living in just under two hundred states with complicated histories of intergroup conflict and historical injury, most, if not all states are to some degree post-conflict societies. This article examines both victimization experiences and narratives through the eyes of peace activists and leaders who work in a binational capacity with Jewish Israelis and Palestinians. Hundreds of peace organizations active in Israel and Palestine, this project focuses on those specifically directed toward opening and cultivating spaces for empathetic engagement across the lines of identity. These include, for example, the Abrahamic Reunion, Breaking the Silence (Indigenous Defense Fighter (IDF) Veterans offering witness testimony on the human rights violations under the occupation), the Bereaved Families Forum, and Combatants for Peace. This article reports preliminary findings from four of 26 interviews conducted with binational peace activists during the summer of 2016.
\end{abstract}

Keywords: Middle East Conflict, Israeli-Palestinian Conflict, political psychology of conflict, peace studies

\section{What Exactly Is in Dispute?}

Most political leaders and expert analysts perceive the dispute to be a conflict over territorial borders, and the tangible resources and jurisdiction within those borders, as well as about more elusive issues of Jewish-Israeli and Arab-Palestinian identities insofar as they are asserted to legitimize territorial claims. The territorial dispute focuses on the final sovereign status of Palestinians and the territorial status of the already-sovereign Israeli state. Issues raised about the final sovereign status of Palestinians include: recognition in a Palestinian state or some kind of sovereign confederated "entity"; the validity of Palestinian claims to the West Bank/Palestine; whether "Judea and Samaria" should be annexed permanently to Israel; whether Palestinian sovereign statehood is a practical possibility; whether it will raise the perceived level of threat to

Franke Wilmer, Professor, Ph.D., Department of Political Science, Montana State University. 
Jewish Israelis from Palestinians; where exactly the boundary will be; and what will be the status of water resources currently shared, but under the control of the Israeli government, and under the surface of Palestinian/West Bank territory.

While none of these questions can be answered here, understanding how Israeli and Palestinian identities are constructed in relation to the conflict necessitates identifying the questions associated with the ongoing "conflict narrative". Another question, however, can be answered with a high degree of confidence, and that is "what will happen if the occupation continues"? The answer is: "continued violent Palestinian resistance in the form of attacks on soldiers and settler and more arbitrary violence directed at Israeli civilians in and outside of the West Bank/Palestine". This view is acknowledged by the Israeli security agency Shin Bet (Winer, 2015).

The identity questions are thornier, but no less critical to understanding, if not resolving the conflict. Must Israel be recognized by Palestinian leaders as a Jewish state? Why and what does that mean? Do Palestinians constitute a distinct identity group of people who were self-determining prior to British colonization, or is Palestinian identity a mostly local Arab identity shared by Muslims and Christians who lived under the rule of successive empires and are now entitled to a sovereign state in the aftermath of British decolonization? Can a mostly Jewish Israeli state and a mostly Palestinian, Palestinian state become pluralistic democracies while maintaining their distinct character as the states of two peoples with two identities?

There are those on the far right in Israel who regard West Bank Palestinians as Arabs living in Judea and Samaria, a region of Israel. There are those in Palestine who use the language of hate-speech, declaring their intention to "drive the Jews back into the sea". But most Palestinians regard the Israeli state as permanent and its legitimacy as irrelevant to its permanent existence. And most Israelis acknowledge that Palestinians are "here to stay" although they have not settled the paradox of having and using enough tangible and immediately deployable power to rule over Palestinians by force while regarding themselves as living in a democratic state that includes those same Palestinians. "Those who think the Israelis will go away, disappear, are living in a fantasy", said Bedouin Muslim educator Sanna Albaz, shaking her fist (Abrahamic Reunion, 2015). "And those who think the Palestinians will go away, disappear, are living in a fantasy. Israelis and Palestinians are here to stay".

But how will they live together? We start by understanding how they live together now.

\section{Land, Water, Walls, and Checkpoints}

This section will briefly describe the conditions, main features, and effects of Israeli control over most of the West Bank/Palestine. Israeli and Palestinian views of these conditions, known collectively as "the occupation". Here, four of the most pressing conditions that affect daily life in the West Bank/Palestine are described: the checkerboard jurisdiction and population in the three Oslo-designated areas of the West Bank/Palestine; the wall or security fence that both divides Israel from Palestine and in some cases encircles whole Palestinian towns; the distribution of water sourced on the Palestinian side of the green line; and the use of checkpoints in the West Bank/Palestine by the Israeli government to restrict the movement of Palestinians, according to the government, for security purposes.

Al Jazeera reported that in the last two months of 2015, the government of Israel built more than 12 new checkpoints in East Jerusalem, bring the total number of permanent checkpoints in the West Bank/Palestine to over 100 (Deger, 2015). The Israeli Human Rights NGO B'Tselem shows a lower number for 2016 and offers a breakdown of permanent checkpoints, "pop-up" or temporarily manned checkpoints, green line checkpoints, 
and internal checkpoints including 12 in Hebron alone (B'Tselem, 2016a). Palestinians are also prohibited from using 41 roads or sections of roads in the West Bank/Palestine, making up over 700 kilometers of roadways (B'Tselem, 2016a). In addition to manned checkpoints, there are numerous unguarded earth and concrete roadblocks, mainly located in the middle of the areas where Palestinians live. Permits are issued for travel through checkpoints, but they can be annulled on short notice, for example, following the June 2016 attack in Tel Aviv, when permits for Palestinian men age 40 and under were nullified. A January 2016 report by the United Nations Office for the Coordination of Humanitarian Affairs counted 452 "pre-existing obstacles" and an increase of $20 \%$ or 91 new checkpoints or barriers built in the last quarter of 2015 (Middle East Monitor, 2016).

I went through three checkpoints in the summer of 2016: the checkpoint separating Israeli and Palestinian areas of Hebron; the Qalandiya checkpoint outside of Ramallah; and Beit Lehem, although there I was already on a bus leaving the city and the soldiers only made men get off to be checked outside the bus while walking through the bus checking the IDs of the women who remained. Qalandiya was a different story. Qalandiya is in the occupied territory, with an Orthodox Israeli settlement and Palestinian refugee camp nearby. In 2015 and 2016 there were several violent encounters between Israeli Defense Forces (three shot, none killed) Palestinian police (one shot and killed), and Palestinian civilians (two killed by Indigenous Defense Fighter (IDF) after a gun battle in the refugee camp) (Frykberg, 2015; Lappin, Toameh, Lazaroff, \& Keinon 2016). Here's how Mohammed Qtaish, a construction worker, describes his commute from Ramallah:

The checkpoints have made so many problems and delays. I am late to my work, my business. It's a pain. First I cross Qalandia, then the one through Wadi Joz, and now this checkpoint [in Suwwana], so that's three I cross. Today, Qalandia checkpoint alone was an hour. Wadi Joz was a quarter of an hour to 20 minutes; this one was the same. I need about two hours to get to work just because of the checkpoints.

The checkpoints are located primarily along the concrete barrier erected to control the movement of Palestinians across the "green line" between Israel and the West bank/Palestine. Called the "separation barrier", "security fence", "apartheid wall" or "anti-terrorist fence", construction began in 2002 in response to the second, markedly more violent intifada. The Israeli Ministry of Defense anticipates a 422-mile completed structure mostly two meters high and reinforced with electrified barbed wire and vehicle barrier trenches, although in urban areas it reaches eight meters in height. It is more than twice the length of the actual green line marking the 1967 borders. It zigs and zags to include a substantial amount of cultivated Palestinian land and several villages. One town, Beit Sahour, a mostly Christian Palestinian village five miles southeast of Jerusalem, will be completely encircled. When organizers of a non-violent anti-occupation protest marathon in Beit Lehem attempted to map out a 26-mile route for the event, they had to circle a smaller route twice because no single 26-mile un-walled stretch of land could be found.

\section{Status of West Bank/Palestinian Land}

However well-intentioned the 1993 Oslo Accords were, as a "roadmap" to the two-state solution, most two-state solution supporters now consider the agreement to be seriously flawed by not tying the plan to transfer control of the West Bank to Palestinian authority to a timetable. Oslo designated three areas of jurisdiction in the West Bank/Palestine, creating a checkerboard of jurisdiction, population, and resource distribution. Area A, consisting entirely of large urban cities, is under complete Palestinian control; Area B is under Palestinian Civil authority and Israeli Military authority; and Area $\mathrm{C}$ is under both civil and military 
authority of the Israeli government. Area $\mathrm{C}$ is the site of most of the present-day violence because it is very rural, sparsely populated by Palestinians, and the site of Israeli settlements, deemed illegal by the International Court of Justice. In addition to settlements openly supported and built by the Israeli government, there are some "outposts" considered illegal even by the Israeli government, although they also receive protection from the IDF and have access to water and energy utilities. Other military outposts built and regarded as legal by the Israeli government often "transfer" to permanent civilian settlements. Additionally, the non-military settlements include a "security perimeter" and settlements are often built in prime agricultural areas that include pre-existing olive groves and fig trees.

The settler population in the West Bank alone grew from 264,400 (including East Jerusalem) when Oslo was signed, to 547,000 in the West Bank/Palestine and 196,890 in the Israeli neighborhoods of East Jerusalem by 2013. The problematic expansion of settlements was noted as early as 1998 for its capacity to undermine the ability of the Oslo accords to serve as a road map to Palestinian self-determination. B'Tselem lists 247 settlements of all kinds including those in East Jerusalem, including 125 government-sanctioned settlements outside of East Jerusalem and another 100 "unofficial" outposts (B'Tselem, 2016a). Below is a summary of the distribution of land in Areas A, B, and C as well as the "state lands" confiscated by the Israeli government (Vexler, 2012a). Settlements are organized by settlement councils that assert de facto control over $86 \%$ of the Jordan Valley and Dead Sea area (IRIN, 2013).

Table 1

Distribution of Land Status in West Bank Areas A, B, and C

\begin{tabular}{cl}
\hline Areas A and B combined (42\%) & \\
\hline Area A & $18 \%$ \\
Area B & $24 \%$ \\
\hline Area C total (58\%) & $30 \%$ \\
\hline State lands & \\
Nature Preserves & $5 \%$ \\
Military areas & $15 \%$ \\
Settlements & $7 \%$ \\
Palestinian villages & $1 \%$ \\
\hline
\end{tabular}

In addition to a military and settlement occupation, the Israeli government destroys housing of the West Bank/Palestine both in retaliation for terrorist attacks and for purposes such as taking over an archeological site, even if the site includes artifacts of both Israeli and Palestinian origin. Susya, which is in Area C, is one of the best known site, and the site of decades of legal battles and activism in defense of the Palestinian villagers. In the summer of 2015, 28 diplomats from Europe join international movement demanding that demolition orders were rescinded. A village in the Hebron hills of the Judean Mountains, Susya today is a village of several hundred goat herders and their families, and the archeological site of fifth to eighth century CE synagogue and later, a mosque. It is also the site of an Israeli settlement and an illegal outpost (keeping in mind that under international law, both are considered illegal). Initially expelled in 1985, the villagers are repeatedly rebuilt, and their buildings are repeatedly razed by the Israeli government.

The Hebrew University's David Shulman, a professor of Hindu literature and philosophy, has long been involved on behalf of the Palestinian villagers, reports one local man as putting his situation this way:

\footnotetext{
${ }^{1}$ State lands refers to land confiscated by the Israeli government
} 
They're calling our village an illegal outpost. These lands are ours from before there was a State of Israel. My father is older than your state - and I am an illegal alien on my own land. I ask where is justice? Your courts distinguish between the settler and the Palestinian... We're surrounded by illegal outposts [built by settlers] that have everything - infrastructures of water and electricity — despite the fact that these settlements are illegal even under Israeli law. And now you want to expel this old man from his home once again? To expel all of us who own these lands, who have lived on them for generations in this space that is ours, which do all we know (Shulman, 2012)?

As of August this year, the Israeli High Court was reviewing an order of the Israeli government to demolish the Palestinian homes in Susya.

\section{Water in Israel and Palestine}

According to B'Tselem and Amnesty International, the main water source shared by Israelis and Palestinians is the Mountain Aquifer located mostly under the West Bank/Palestine and replenished by rainfall there. It supplies about $25 \%$ of the water needs of Israel and the settlements and nearly all of the water accessible to Palestinians. Eighty percent of the aquifer's water goes to Israel and the settlements and $20 \%$ goes to Palestinians, according to the 1995 Oslo 2 agreement.

Nearly 400,000 Palestinians live in areas with no running water or very limited water access. They use cisterns, buy water from private companies, and use natural springs (Vexler, 2016b). Some springs have been taken or obstructed by settlers, for example, in the village Nabi Saleh, or in the goat herding village of Susiya. With $43 \%$ of Palestinians living below the poverty line and per capita annual income in the West Bank/Palestine currently around $\$ 3000$, purchasing water from private companies is not an option for many Palestinians.

The World Health Organization recommends 100 liters per person water consumption per day. Israel and the settlements average 242 liters per day per person, while the average in the West Bank/Palestine is 73 liters per day with some areas, refugee camps mainly, are in the range of 36-44 liters per day.

Like everything else, water use is complicated. Oslo created a Joint Water Committee to review proposed new projects from both sides, but in practice Israel is able to sidestep approval for many projects because of its control over Area $\mathrm{C}$, while Palestinians need approval for all infrastructure projects that would give them to access their full $20 \%$ share. Instead they are only able to access about $15 \%$, according to B'Tselem. Furthermore, Israel can veto drilling projects in Area $\mathrm{C}$, and throw bureaucratic obstacles into the approval process, effectively delaying even those projects that are approved. According to B'Tselem, a facility in western Nablus submitted to the committee in 1997, only began operating in 2013" (B'Tselem, 2016b).

\section{Jewish Israeli Views of the Occupation}

A 2013 poll reported that 53\% of Jewish Israelis opposed ending the occupation and 39\% supported ending it (Gluntz, 2013). More recent polling on religion and politics in Israel by the Pew Research Center, in which more than 5000 Israelis were surveyed, showed that almost half of Israeli Jews said "Arabs should be transferred or expelled from Israel", and in almost equal numbers, 46\% disagreed (Lipka, 2016). So how do Jewish Israelis view the occupation? Yet another recent poll, this one conducted by the Israel Democracy Institute in May 2016, reported that 71.5\% of Jewish Israelis do not consider Israel's control of the West Bank as an "occupation" (saying they are either "sure" or "think" it is not occupation), while the same percentage of Arab respondents do (Times of Israel Staff, 2016). 
Jewish Israeli views of the occupation can be broken down into roughly three camps. One regards the assertion of military and civil authority in Area C and military authority in Area B along with the system of checkpoints, travel restrictions, and settlements, as creating a "buffer zone" in territory taken from Jordan in the 1967 war. The second view is that the occupation today, regardless of its origins, is necessitated by the continuing threat to Israel's security by surrounding Arab states, and the continuing Palestinian attacks on Israelis (in Israel and in the West Bank). They don't like the occupation, but believe it has reduced Palestinian attacks and they don't see another way. Military control of the West Bank and restrictions on Palestinians' freedom of movement is defensively necessary to the security of Israel, in this view. Some Israelis oppose the occupation altogether. This is the third view.

Many proponents of the original "buffer zone" view regard the land as taken "fair and square" so to speak, as a spoil of war, and inclusive of land that Jews historically inhabited prior to the Diaspora that expelled and dispersed most of them throughout Northern Africa, neighboring Arab states, and Europe for nearly two millennia. This view is linked to the Israeli foundational narrative that while most Jews were forcibly dispersed, some remained, and after 1900 years of persecution culminating in the Holocaust that killed half the world's Jewish population, they have at last come home to create a Jewish state, the only place where the world's Jews can truly be secure. Perhaps it is the way these two sub-narratives are linked that leads such a large majority of respondents in the May 2016 poll to say they "think" or "are sure" that the Israeli government's rule over the West Bank is not an occupation (Times of Israel Staff, 2016).

In this view, the buffer zone itself is actually part of Israel or should be, and is commonly referred to the area as "Judea and Samaria". How can you militarily occupy a place that is already part of your country? When asked in May 2016 "To what extent do you fear that you or one of the people important to you will be harmed in the current wave of terror attacks?" sixty-four percent said they were "greatly or moderately" afraid, down five percent from the previous month. By a small majority, 52\%, the same respondents said that it was more important to have a Jewish majority Israeli state than to have sovereignty over "off of the historical lands of Israel" (referring to the West Bank) with only $22 \%$ in the same poll placing sovereignty over a "greater Israel" as more important (Times of Israel Staff, 2016). This probably accounts for the relatively large number of Jewish Israelis who still support a two-state solution (51\% in an August 2016 poll, down from 61\% in 2014). Many believe that the wall/barrier is responsible for a decline in terrorist attacks (Steves, 2011), although others, including some on the right, believe that the reduction in terrorist attacks was brought on by the success of the 2002 "Operation Defensive Shield" undertaken to end the second Intifada (Y. HaKohane, personal communication, June, 2016; Amir \& Hashavua, 2015).

Finally, 39\% of Jewish Israelis support ending the occupation altogether. This view is shared by most or all Israeli peace groups and all binational peace groups as well as specifically anti-occupation organizations like the former-IDF soldiers of Break the Silence and Combatants for Peace. In this view, the occupation is simply wrong from a moral perspective, or it is ineffective, and for some, counter-productive - a cause of Palestinian violence. The binational peace groups and witnessing projects like Breaking the Silence seem to be garnering increasing support or sympathy in the public, though especially the latter, certainly not from the Israeli government. At least one Jewish Israeli political leader has been outspoken about claiming that the occupation is causing violence in resistance to the occupation. In June 2016, following an armed attack on civilians in a Tel Aviv restaurant that killed four people and wounded six more, Tel Aviv Mayor Ron Huldai, himself a former Israeli Air Force pilot, called on Israelis to acknowledge that their country "is perhaps the only country in the 
world holding another nation under occupation without civil rights", adding that "There is no way to hold people in a situation of occupation and think that everything is okay and they will continue to live like that" (Konrad, 2016). This is not the bold outlier it may appear to be similar links between Palestinian violence and resistant to Israeli occupation were suggested by former Prime Minister Ehud Barak and the security agency Shin Bet (Konrad, 2016; Winer, 2015).

\section{Palestinian Views of the Occupation}

Most Palestinians living in Israel-77\% in a 2014 poll, many of whom see themselves as Arab Israelis, want to continue to live in an Israeli state. But $30 \%$ also believe Israel bears responsibility for terror attacks (Radai, Elran, Makledeh, \& Kornberg, 2015). It is safe to say that Palestinians oppose the occupation universally, although there is disagreement on the most pressing goals of Palestinians in the West Bank/Palestine. Only $48 \%$ see the occupation as the most pressing problem today. Thirty percent believe that obtaining a right of return for refugees dispossessed in 1948 (what they call the Nakba or "catastrophe") is the most vital concern, while $12 \%$ believe that building a "pious or moral individual and religious society" is most important, and $11 \%$ believe building a Palestinian democracy should be the highest priority (Palestinian Center for Policy and Survey Research, 2016).

Is the occupation a case of apartheid, ethnic cleansing, or an act of aggression aimed at the ultimate de facto goal of annexing the "occupied territories" to the state of Israel once it becomes impossible to create a Palestinian majority in much of the contiguous territory even in the West Bank? Area A has in effect become a scattering on Palestinian controlled enclaves within territory under the military authority of the state of Israel (in areas B and C). Already the settler population rivals or exceeds the Palestinian population in Area C.

With the building of the wall or barrier, the use of the term apartheid to characterize the Israeli government's policy toward Palestinians came into widespread use. But it was the architect of South African apartheid, then Prime Minister Hendrik Verwoerd, who first articulated the analogy in 1961, saying "Israel, like South Africa, is an apartheid state" (Clarno, 2009, pp. 66-67). Israel's oldest newspaper, Haaretz, regarded as left or center-left, has been the site of debate on both sides. One writer who says he had long resisted the analogy, recently announced "It's Time to Admit It. Israeli Policy Is What It is: Apartheid", while another who has recently published a book investigating the claim, concluded that "Israeli Policy Is Not Apartheid" (Burston 2015, Pogrund, 2015).

However, another narrative using a different analogy among Palestinians and Jewish Israeli critics of the occupation view it as part of a grander strategy of ethnic cleansing that has its roots in the 1948 war and the expulsion and killing of many Palestinian civilians. As is often the case with unreconciled and unacknowledged historical injury - think American genocide against indigenous peoples-debates continue about how many Palestinian villages were destroyed because of the war or as a "military necessity" for winning the war, versus how many Palestinian civilians were killed whose death were entirely avoidable and how many were evicted from their homeland in abstensia. Gideon Levy reports that the Oslo negotiations acknowledged that 140,000 Palestinians who were not even present during the war, were dispossessed.

Students who went to study at foreign universities, businessmen who tried their luck abroad, scientists who went abroad for professional training, native Jerusalemites who dared to move to the West Bank temporarily, they all met the same fate. All of them were taken by the wind and expelled by Israel. They couldn't return (Levy, 2011). 
In this analogy, cleansing all of then-Palestine by excess expulsions and killings during and after the war were just the beginning. Travel restrictions placed on Palestinians by the Israeli government (including international travel); water rationing; establishing military outposts and settlements in Area $\mathrm{C}$ and East Jerusalem; and demolition of homes in retaliation for terrorist attacks as well as because inhabitants are denied or unable to obtain proof of ownership - are all tactics aimed at driving Palestinians out of Palestine. Again Gideon Levy reports that making "the lives of Palestinians in the territories miserable to get them to leave" has been a success, with 250,000 leaving between 2000-2007 alone (Levy, 2011). The Israeli anti-occupation human rights NGO B'Tselem reports that,

From 1967 to 2005 Israel demolished hundreds of Palestinian homes in the occupied territories as a punitive measure... In early 2005 the Israeli Defense Minister adopted the recommendation of a military commission charged with investigating the issue and ordered home demolition as a punitive measure cease. His decision was made partly in view of the commission's finding that the deterrent value of demolitions had not been proven, and that the policy may in fact have the opposite effect. (B'Tselem, 2016c)

Still, demolition orders and demolitions continue. More homes were destroyed in the first six months of 2016 than in all of 2015, leaving 740 more Palestinians homeless (B'Tselem, 2016d).

Finally, both Palestinians and Israelis seem caught in a web of hopelessness and despair of change. Two things I heard from nearly everyone I interviewed this summer were "we can't go on this way" and "I cannot see how things will change". I was not alone in this observation. In December of 2015 the New York Times Jerusalem Bureau Chief Jodi Rudoren published a widely cited and republished video describing "how the despairing sentiment has deepened over the years" and that "There is a deep hopelessness in the Palestinian society about their own future and in the Israeli society about the possibility of an agreement" (Brekke, 2015). Last year the Israeli security service Shin Bet also reported that "Hopelessness [was] fueling recent Palestinian attacks", saying that "For some terrorists, attacks allow an escape from a bleak reality which they perceive as unchangeable" (Winer, 2015).

\section{On the Ground: Voices from Israel and Palestine}

In May and June 2016 I traveled to Israel and Palestine to make on-the-ground contacts, observations, and interviews. I interviewed at length 25 people individually, went on two "narrative tours": one to Beit Lehem conducted by the Combatants for Peace, and the other a "dual narrative" tour of Hebron co-conducted by Jewish Israeli and Muslim Palestinian guides. I was also fortunate to be invited to join a small conference on the Israeli-Palestinian conflict at the Hebrew University co-convened by the Davis Institute for the Study of International Affairs and the Swiss Center for Conflict Research. Presenters included many of the most prominent and experienced local researchers and experts from the Hebrew University, Tel Aviv University, University of Haifa, al-Quds University, Bar Ilan University, and a journalist from the Al-Monitor, a prominent source of Middle East news.

I began my interviews with a set of questions, but soon gave up on the idea of keeping my respondents "on task". They wanted to tell me their personal stories, and I came to appreciate that there may be more to learn about the conflict and prospects for peace through the unmediated stories of lived experience. Each respondent is actively engaged in non-violent peacemaking as well as working with people from both sides. The "binational" orientation whittled down my focus on peace groups from the hundreds, mostly on the Israeli side, working (though working on that side to oppose occupation, or support Palestinian human rights, like Breaking 
the Silence or Rabbis for Human Rights) to a half dozen or so.

I have fully transcribed four of the interviews, which are often over an hour in length. I chose these four for this article because they represent diverse views and experiences. Two are women and two are men, two are Jewish Israelis and, one a Palestinian Muslim, and one a Palestinian Christian. There are about 175,000 Palestinian Christians living in Israel and Palestine and another 3,000 in Gaza. Three of the interviewees are in their early 70s, one is in his 30s. Two of the three elder interviewees lived in Palestine under British rule, prior to the creation of the state of Israel, and the third lived in Gaza and Egypt. All are actively engaged in binational peace organizations and efforts, three are founders of such organizations. I will briefly describe the life and work of the individual as well as what their interviews tell us about how they view the present conflict, including how they came to the decision to work in a binational manner on peace building and the prospects for resolving the conflict in the future.

\section{Roni Keidar}

Other Voice is a binational peace group working in the Sderot-Gaza region. Maintaining relationships across the Jewish Israeli-Palestinian divide became much more difficult after the withdrawal of Israeli troops, dismantling and relocating Israeli settlements, and the closing down of the Gaza-Israel border in 2005. Other Voice was started in 2008 by two bloggers — one from Gaza, one from Sderot. Roni became active in the group in 2009 after returning from four years living in Egypt (she and her husband, an Egyptian agricultural scientist, had previously lived in norther Sinai but had to evacuate in 1982 in accordance with the Camp David Accords). Other Voice's slogan is "For a Civilian Solution to the Conflict".

There is a movement among some Palestinians referred to as the "anti-normalization" movement, so named because they oppose any activity that "normalizes" the occupation. Roni spoke about the "anti-anti-normalization" sentiments among Palestinians because binational peace groups are often criticized for undermining the anti-normalization movement.

She said, there are more people in favor of peace and against the anti-normalization movement but they have been afraid to openly express those feelings until recently, when you see more people saying "No more, I am doing nothing wrong, so I won't hide".

She added that peace movements, of which there are hundreds in Israeli, can be very abstract and there is a good case to be made for keeping them local where they can work "on the ground" to open spaces for dialogue and empathy.

When we talk about peace here, we are neighbors, and I believe that as long as their life isn't worth living, then neither is mine. That is one of the mottos of Other Voice- "Life There Equals Life Here". We carry a message that you can feel in your heart and in your mind, it is the message of real people trying to live together, like Bereaved Families Forum, that's why it is far more meaningful.

For me, living in Egypt was a real eye opener because until we traveled there I knew only the Jewish side of the history, about the Diaspora, the Holocaust, and the establishment of the Jewish state for the Jewish people. As far as I was concerned, we could do no wrong. Everything was perfect and right. All of a sudden I meet people and hear another side to this very same story. I must tell you that it makes life very difficult when suddenly you must consider the other side of the story.

Encountering "the other", Roni was able to open a space for empathetic engagement. 
It is very easy when you know one side. While I was there [in Egypt] I realized the importance of dialogue. People who refused to speak to us just because we were Israeli. I managed to find a way to meet and to talk - not necessarily to talk about who is right and who is wrong, but to talk about our lives, what had happened to them and what had happened to us.

But, she says, there are many in her agricultural village today, just a few hundred meters from the Gaza border and where residents sometimes hear tunnels being dug out beneath their homes and gardens, who do not believe peace is possible. She says, "They say 'these people are firing rockets at us and you want to say stop, stop, I want to talk?' 'Of course not', I say”.

But there are times in between. We want to connect with the people in Gaza. We want to know them, explain who we are... One way to get out of Gaza is if you need to be taken to a hospital, so every now and then I go down and pick up people and take them to the hospital and we get to talk along the way. Some I never see again, but with some we make real connections.

Roni also describes the group's effort to create events that publicize their work. One was called "Bridges Instead of Tunnels". Although the mainstream Israeli media minimized its coverage, she and her husband, a fluent Arabic speaker, were pleasantly surprised to find the best coverage on Al Jazeera.

\section{Rabbinit Hadassah Froman}

Hadassah Froman is the widow of Rabbi Menachem Froman, who died of cancer in 2013. Rabbi Froman was a paratrooper in the military takeover of the Western Wall in the 1967 war, and a pioneer in peacemaking and interfaith dialogue as a path to conflict resolution. He and his wife were firmly committed to the idea that religion could and should be a part of any effort to resolve the conflict and bring about peace and engagement between the two communities, believing that religion can be a tool for recognizing common humanity and the dignity of all people. He was a settlement founder in the Gush Emunim movement and the chief rabbi for the community of Tekoa in the West Bank and was also the Chief Rabbi of the Knesset.

Rabbi Froman was involved in negotiations and peacemaking efforts with religious leaders from Hamas and the Palestine Liberation Organization (PLO) and in 2008 took part in drafting a ceasefire between Israel and Hamas in the Gaza Strip. The agreement was known as the Froman-Amayreh Agreement, jointly named for him and his Palestinian partner, Khalid Amayreh, a journalist with close ties to Hamas. Although the agreement was not enacted, Rabbi Froman held that it could serve as the basis for future negotiations.

Rabbi Froman supported Jerusalem as the capital of both states, and advocated for the withdrawal of Israeli military forces in the West Bank while leaving Israeli settlements in place, and transferring sovereignty to a Palestinian government. Although he supported similar moves in the Gaza Strip, he did not support the unilateral disengagement and eviction of Jewish settlers, which happened in 2005. The resulting power vacuum led to internal violence and eventually, the rise and consolidation of a Hamas-run government. Instead of improving relations, the disengagement was followed by a hardening of hostilities evidenced by several rounds of armed conflict, kidnappings, and an increase in arms smuggling and terrorist attacks in the years that followed (Baker, 2015). Many people now consider the disengagement and eviction a failure because it disengaged the co-existence of Palestinians and Jews in Gaza, which Froman considered as an essential element of stable peace. It is also regarded as portentous for the future of settlements in the West Bank (Ben-Meir, 2014). 
Hadassah Froman and her future husband were both born in the Galilee under the British mandate of Palestine. Their lives were tightly interwoven around the interfaith peacemaking work of Rabbi Froman and Hadassah continues that work today. They had 10 children, now grown, and in January 2016, their pregnant daughter-in-law was injured in a knife attack in the Jewish settlement of Tekoa, in the West Bank, where Hadassah lives today. From her hospital bed a few days after the attack, Michal Froman expressed empathy for her attacker, a teenager who was shot after the attack by an armed civilian and taken into custody by security forces.

To be stabbed with a knife from up close is something very personal, and I wondered what he went through, why he's doing it, what does he want to get out of it? To be one of the martyrs? To be part of something? I don't know. She said. 'I didn't wonder why he didn't kill me because it very much seemed to me that he came to stab and escape, to achieve some purpose that was not to kill me. I don't know what his story was" (Winer, 2015).

Hadassah and Menachem's son and Michal's husband, Shivi Froman, is, like his parents, committed to peace through interfaith dialogue and engagement, saying, after the attack, that it only "strengthened" his "opinions".

"God dwelled in the love between one man and one woman", said Hadassah of her spiritually-inspired marriage to Menachem.

For Menachem and me our connection was the main point of our life and all the world was the meaning of our connection and work. Menachem believed that in all the connections between people are found the presences of God... and it is the same with Arabs and Jews. The connections where the two sides meet each other are the covenant between them.

"If you separate nothing happens. No blessings will come through. Especially here in this earth, this holy land-we are drawn to this connection", she continued.

This is our natural inclination for the children of Abraham to be drawn to each other. The conflict is a result of that too - the conflict is not because we are separate but because we are so close... Every day I have connections with Palestinians by phone, meeting, and so on. And I always feel that they give me something that I cannot get from my Jewish people. I think there is a balance that can happen in the encounter between the people. We are the place of the changing of the whole world and we can do it. We have to do it.

\section{Elias Jabbour}

Elias and Heyam Jabbour have worked for peacemaking and reconciliation since 1978. They live in Shefa-Amer (Shefar-Am in Hebrew) in the Galilee region. In 1993 they were awarded the "International Courage of Conscience" for their work. Two years later they received another award for fostering interfaith dialogue in Israel and Palestine. Eighty-five leaders from Israel's Jewish, Muslim, Druze, and Christian communities gathered in the Jabbours' House of Hope in Shefa-Amer to engage in dialogue aimed at identifying common peace and human values across diverse religious communities.

Mr. Jabbour learned about the traditional Palestinian peacemaking process called sulha from his father, who was a highly respected sulha leader. Sulha is the process of peacemaking and reconciliation that westerners would call restorative justice. It is used when families or communities fall victim to violence the consequent loss of loved ones. It is an elaborate system that rests on the parties' willingness and desire to achieve a peaceful outcome, and includes a period of disengagement called hudna. It inherently recognizes that 
violence, loss, and reconciliation are fundamentally emotional experiences and therefore require parties' taking the time needed to emotionally process their losses, their anger, and their grief before beginning the sulha. He explained that hudna "is the carpet for peace, give people time and space and let them talk about the problem".

In Yiddish there is a word for the emotion in your stomach, it is a thing you carry in your stomach and until you get it out you won't be able to move past anger. Jaha (expressing how one feels) is the mechanism for discharging those feelings - the shock absorber.

Elias told me about his experience accompanying his father to conduct or begin a sulha with two families. The goal is peace. The goal is to make a solution that both sides agree to. How to make a person who lost his beloved son make peace with the killer. I learned it from my father. I went with him to a sulha case and they told me this old man lost his son and the man carrying the white flag was the killer. And the old man shook hands with the killer and I asked my father "How can this be?" and my father said, "This man lost one son and this way he will not lose another". They ended the cycle of violence. I tell the Jews and Arabs "we make sulha in order not to lose more! For the sake of the living!" When we make sulha it is not to lose more, even with a high price.

No one I talked with used the word "peace" more than Mr. Jabbour.

I find in history almost all nations all the time... when they hear the drums of war, people march very quickly, but here we are all the time calling "Peace! Peace!" and no one listens. We studied in schools - peace , peace, peace - and yet no peace. All religions are about peace and love but I don't see religious people following the path of peace. At least not the people in power. What is the problem between Arabs and Jews? To convince them that peace is better than war. Some people say peace is risky, they cannot afford to take this risk because war protects us and so on. This is indoctrinated in our minds and this is wrong. War is risky, and expensive, and destructive. But peace can protect you very cheaply. So I say to Arabs and Jews, "Try peace just once. If you don't like it, you can always go back to war!"

We talked about his own upbringing and how he came to see diverse views of history including the Jewish experience.

I grew up in a different time, before 1948, in Palestine, when we were villagers. Life was simple. No water. No electricity. No car. We got water from the well. When you have to work hard and work the land there is no time to fight. The land is very generous. When you give it a piece of corn it gives you a hundred pieces back. I grew up in Palestinian society and knew nothing about the other side, Jewish or Israeli or whatever you want to call it.

Elias grew up under the British mandate and, he says, "we studied under the British and dreamed the British would send us to Oxford". Then the British withdrew, and Jews came to occupy his home town of Shefa Amer, where his father was the mayor. All Elias wanted was to continue his studies, he said. "And just like that I was transferred 180 degrees from an old to a new world. Instead of going to London or Oxford, I went to the Hebrew University in Jerusalem, without learning any words in Hebrew".

We have an Arabic proverb that you are afraid of something you don't know. We didn't know the Israelis, we knew nothing of the Jews, and we never met them. I opened my eyes on the Jewish ocean! I almost drowned in the Jewish ocean! I thought all Jews were the same-I didn't realize there are hundreds of Jews, hundreds of ways to be a Jew. It was 1957 when I went to the Hebrew University and began to learn about the different Jewish communities. Where did I live? You won't believe it. Mea Shearim, I almost spoke Yiddish! I 
used to walk the street and they called me "Jew! Come to minion!" What is the point of telling them I am not Jewish? It was easier just to go to minion. If the walls can come down between me and the Jewish people, then all the walls in the world can fall.

As a peacemaker, Elias sees justice and peace as inseparable. "One of the main principles", he said, "is human dignity. A humiliated person cannot make peace. We have to restore dignity before restoring rights. Dignity is more related to justice but I would say justice and peace go together".

\section{Sulaiman (Souli) Khatib}

Souli's family lives in Hizma, a Palestinian village about 25 minutes from Jerusalem. Their land was taken by the Israeli government in 2007 in order to build the barrier/wall. "We had to remove the Roman olive trees", he said, "We call them Roman because they are really old". Souli describes his family as "nationalistic" and says "I was raised in a family which was badly affected by the occupation and fought it. According to their outlook, the only possible solution is a military one" (Khatib, 2016). At the age of 12, he joined the Fatah movement and became a "fighter" for his people, throwing stones and making Molotov cocktails, even before the first Intifada. "At the age of 14, I stabbed Israeli soldiers with a friend of mind. We were arrested. I was sentenced to 15 years in jail and my friend to 18 years" (Khatib, 2016). He was taken to the children's quarters in the Hebron prison where Kiryat Arba settlers served as staff. According to Souli, the prisoners often lacked potable water, were unable to take showers, and were subjected to stripping, tear gas sprayed into their cells, and beatings on a daily basis.

After his transfer to a new prison he worked in the prison library and began to read Jewish history and attended "learning groups".

I began to see two narratives - well there are more than two - but I see the big picture and not just from a victimhood point of view. I try personally through Combatants for Peace and other forums for peace and change and freedom to make a change where I can not wait for the governments to reach an agreement. For me I don't see any other way than a joint Palestinian-Israeli nonviolent movement that aims to end the occupation and end the violence and make a change here and make reconciliation.

Souli engages not only with veteran Israeli Defense Forces combatants, but with settlers as well, saying "You know it is very hard to put your shoes on the other foot and I am aware that I have this ability to empathize with the other side".

It is really hard to understand the Israelis traumatizing about security and so on, but personally I feel sympathy for them because I watched a film about it [the Holocaust] when I was in jail. We were crying of course... At the same time I cannot accept using it like "well, because of the Holocaust we have to take your olive trees. There is no connection there. We have to realize these connections on both sides, we don't need to live in denial now. Israeli exists and there was the Nakba in 1948 and so on, but this is not the war now, and it is not the Nakba, we need to live our lives now".

In addition to a deep commitment to nonviolent action as the path to change, Souli talks a lot about not getting stuck in victimhood and victimization stories.

In our life under occupation, our survival needs, we struggle on a daily basis. We are not privileged, but I don't want to feed that victimhood. We have a responsibility as Palestinians, even though we are the weaker side, to see that we have a lot of power. I do not compare who suffers more, this is a fact of life for us, but it also does not mean that Israelis are safe and secure. You need security and peace. Israelis have a state, they 
have passports and a more normal life, but you still need basic legitimacy, and security, and peace and that's why Israelis also want dialogue, for consciousness and for these things too.

He says that both sides "playing the game of victimhood" is not the path to peace, resolution, and reconciliation, but that Palestinians and Israelis need to "challenge the system and change the story, because if we keep going this way Area $\mathrm{C}$ will be taken, the land will be annexed, and it will not be good for Palestinians or Israelis because this place will never be just Jewish-Israeli or just Palestinian".

We need ideas that are outside of the box because we need to find a way to co-exist and for me, I want safety and freedom for everybody at the end of the day and I am very passionate about it. This is my life, my land, my home, my heart, my soul.

\section{What's Next? We All Want Peace: The Taxi Driver and the Academics}

I heard no single phrase repeated or paraphrased more than "we all want peace" or "we all want the same thing". But it's complicated. One morning as I rode a taxi to the university to attend a conference at the Hebrew University, like all the friendly people I met, the taxi driver asked me what brought me to Jerusalem. I usually said "peace studies" and, knowing how unoriginal that sounds, I would add something about researching peace groups that work with both sides. The driver smiled, and said "we all want the same thing", then added "but they teach their children to hate us". Later that afternoon, I heard similar sentiments from academic experts presenting and discussing the conflict at the conference. But how do we reconcile the competing narratives? How do we disrupt them, and in the name of peace, open a space where people can empathize with one another?

As Sulaiman Khatib said in our interview: In my opinion there is a third narrative that includes Israelis and Palestinians and our connection to the place. This was not really obvious to me back in the days like I used to see Israelis as any other Palestinian as a colonial occupation coming from Europe taking our home land. Now I see it a little different of course I believe we must end the occupation but I respect and I have sympathy now to our both Palestinian and also the Israeli-Jewish connection and history here.

He added that: Due to the reality, every day we live with the difficulty of exiting the wall at check points, just the logistics of meeting our survival needs, it is hard to have empathy for the conquerors as survivors of their own tragedy, but I would say that humanizing the other side is very important. I don't want to live under occupation, of course, but I personally don't have a problem, for example, with Jewish people living in Hebron, but I do have a problem if they run us by military law.

The U.S. State Department funded a large, 3-year study of textbooks used in Palestinian public and private schools and Israeli public schools including those from grades 1-12. The results generated substantial controversy, embraced by the Palestinian Authority, rejected roundly by the Israeli government. They were widely reported in mainstream U.S. and Israeli media, and include that:

(1) Dehumanizing and demonizing characterizations of the other are rare in both Israeli and Palestinian books.

(2) Both Israeli and Palestinian books present national narratives that portray the other as an enemy and in a generally negative light. Historical events, while not fabricated, are selectively presented to reinforce each national narrative.

(3) The absence of information about the culture, religion, and everyday activities of the other- including the failure to recognize the other on maps of the region—serves to delegitimize the presence of the other. 
(4) Negative bias in the presentation of the other is significantly more pronounced in Israeli ultra-Orthodox and Palestinian textbooks than Israeli state school books (Felsen, 2013).

\section{Conclusions}

To be fair, the study found that negative characterizations were present in about twice as many of the Palestinian books as Israeli books (50\% and 25\% respectively), and they reviewed about three times as many Israeli books (492 Israeli and 148 Palestinian books) (Ziri, 2013). Positive portrayals of the other were found in $11 \%$ of Israeli texts and one percent of Palestinian texts - small percentages in both cases, but 10 times more in Israeli than Palestinian books (Ziri, 2013).

The important question, said Daniel Bar-Tal — one of the lead researchers on the textbook study — during the conference I attended in May, is how does an individual come to reject these characterizations and choose to see the other in an empathetic way? How does an individual open his or her mind to the narrative of the other, and to validating the narrative of the other, even if not agreeing with it? All four of the respondents reported here were able to do that, with three of the four very well aware that they started out at some point with a one-sided view and at a turning point in their lives, came to see the narrative of the other. In the fourth case, Hadassah Froman, it seems as though this was always the view and she and her husband shared, that the "otherness" of Palestinians was valued, that difference, whether between men and women or Jewish Israelis and Palestinians was the natural spiritual order of the world and that connection across difference brought blessings. Palestinian otherness, in their view, was not an inevitable source of conflict and violence. They seemed always to embrace what Souli called "the third narrative that includes Israelis and Palestinians and [their shared] connection to the place".

The experiences that led these individuals to broaden their perspectives and engage empathetically with the narrative of the other centered on interpersonal relationships; proximity in a non-threatening environment. The physical and structural relationship between Israelis and Palestinians today, sadly, moves in the other direction, making interpersonal encounters less likely and erasing neutral space with separation barriers, checkpoints, settlements, and only four bilingual, binational schools in the entire country. Doubi Schwartz, former General Manager of the Parents Circle Families Forum, a group of 600 families from both sides who have lost loved ones to the violent conflict, explained that members of the organization visit high schools in teams of one Palestinian and one Israeli family member to tell their stories of loss and their plea for peace and nonviolence. "Some of the schools in Israel will not let us bring a Palestinian in, and for many who do, it is the first time they have encountered someone from the other side".

These are the questions that will guide my continued transcription and analysis of the stories I heard this summer, and my plans for next summer's research. How to put what we know into action, support for encounters that enable ordinary people to engage empathetically with one another, and how to translate that experience into the demand for leaders on both sides who have the political will to act on that engagement in a constructive way.

\section{References}

Abrahamic Reunion. (2015). Presentation to Bozeman's Interfaith Community. October 14, 2015, Bozeman, MT.

Amir, N., \& Hashavua, M. (2015). Analysis: Israel is one major terror attack away from Operation Defensive Shied 2. Jerusalem

$\begin{array}{lllll}\text { Post. } & \text { Retrieved } & \text { October } & 3, & \text { 2016, from }\end{array}$
http://www.jpost.com/Arab-Israeli-Conflict/Analysis-Israel-is-one-major-terror-attack-away-from-Operation-Defensive-Shie ld-2-421322 
Baker, L. (2015, August 10). Shadow of Israel's pullout from Gaza hangs heavy 10 years on. Reuters. Retrieved October 5, 2016, from http://www.reuters.com/article/us-israel-gaza-disengagement-insight-idUSKCN0QF1QQ20150810

Ben-Meir, A. (2014, November 13). The fallacy of the Gaza withdrawal. The World Post. Retrieved October 5, 2016, http://www.huffingtonpost.com/alon-benmeir/the-fallacy-of-the-gaza-w_b_6152350.html

Brekke, K. (2015, December 3). NYT Jerusalem bureau chief: Israelis and Palestinians feel "hopeless". Huffpost Live. Retrieved October 3, 2016, from http://www.huffingtonpost.com/entry/jodi-rudoren-israel-palestine_us_565dea87e4b072e9d1c378f1

B'Tselem. (2016a). Statistics on checkpoints and roadblocks. Restriction of movement. Retrieved October 1, 2016, from http://www.btselem.org/freedom_of_movement/old/copy\%20of\%20checkpoints

B'Tselem. (2016b). Water crisis: issues under the Oslo accords. Retrieved October 1, 2016, from http://www.btselem.org/water/oslo_accords

B'Tselem. (2016c). House Demolitions as Punishment. Retrieved September 30, 2016, from http://www.btselem.org/topic/punitive_demolitions

B'Tselem. (2016d). Israel demolished more Palestinian homes in West Bank in first half of 2016 than all of 2015. Press Release. Retrieved October 3, 2016, from http://www.btselem.org/press_releases/20160727_house_demolitions_in_area_c

Burston, B. (2015, August 17). It's time to admit It. Israeli policy is what it is: Apartheid. Haaretz. Retrieved October 3, 2016, from http://www.haaretz.com/blogs/a-special-place-in-hell/1.671538

Clarno, A. J. (2009). The Empire's new walls: Sovereignty, neo-liberalism, and the production of space in post-apartheid South Africa and post-Oslo Palestine/Israel. Ann Arbor, MI: University of Michigan Press.

Deger, A. (2015, December 4). Israeli checkpoints: "We live under colonization". Al Jazeera, Retrieved September 16, 2016, from www.aljazeera.com/news/2015/11/israeli-checkpoints-live-col...

Felsen, M. (2013). Much Ado About Israeli and Palestinian textbooks. Retrieved October 7, 2016, from http://www.huffingtonpost.com/common-ground-news-service/israeli-palestinian-textbooks_b_2679223.html

Frykberg, M. (2015, November 16). Israeli forces kill Palestinians at Qalandiya camp. Al Jazeera. Retrieved September 30, 2016, from www.aljazeera.com/news/2015/11/israeli-forces-kill-palestinians-qalandiya-151116091413833.html

Gluntz, I. (2013, August 23). Poll says Jewish Israelis oppose ending the occupation, 53\% to 39\%. Mondoweiss. Retrieved September 30, 2016, from http:://mondoweiss.net/2013/08/poll-says-jewish-israelis-oppsse-ending-occupation

IRIN. (2013, March 18). Briefing: Beyond the E-1 Israeli settlement. Retrieved September 30, 2016, from http://www.irinnews.org/report/97676/briefing-beyond-e-1-israeli-settlement

Khatib, S. (2016). Combatants for peace personal stories. Retrieved October 7, 2016, from http://cfpeace.org/personal-stories/

Konrad, E. (2016, June 9). Tel Aviv mayor says the occupation is a cause of Palestinian terror. +972 Magazine.

Lappin, Y., Toameh, A. K., Lazaroff, T., Keinon, H. (2016). Palestinian police officer shoots three soldiers at check point near Ramallah. Jerusalem Post. Retrieved $\quad$ September $\quad 30, \quad$ 2016, from http://www.jpost.com/Arab-Israeli-Conflict/Initial-report-Three-wounded-in-West-Bank-shooting-attack-443351

Levy, G. (2011, May 12). Ethnic cleansing of Palestinians, or, democratic israel at work. Haaretz. Retrieved October 3, 2016, from http://www.haaretz.com/ethnic-cleansing-of-palestinians-or-democratic-israel-at-work-1.361196

Lipka, M. (2016). 7 key findings about religion and politics in Israel. Facttank: News in Numbers, Pew Resarch Center. Retrieved October 1, 2016, from http://www.pewresearch.org/fact-tank/2016/03/08/key-findings-religion-politics-israel/

Middle East Monitor. (2016). UN: 20\% increase in Israeli checkpoints and roadblocks across the West Bank. Retrieved October 1, 2016, from https://www.middleeastmonitor.com/20160209-un-20-increase-in-israeli-checkpoints-roadblocks-acrossthe-west-bank/

Palestinian Center for Policy and Survey Research. (2016). Palestinian public opinion poll No 59: Press Release, 17-19 March. Retrieved October 2, 2016, from http://www.pcpsr.org/en/node/634

Pogrund, B. (2015, August 25). Israeli policy is not apartheid. Haaretz. Retrieved October 3, 2016, from http://www.haaretz.com/opinion/.premium-1.672904

Radai, I., Elran, M., Makladeh, Y., \& Kornberg, M. (2015). The Arab citizens in Israel: Current trends according to recent opinion polls. Strategic Assessment, 18(2), 101-116.

Shulman, D. (2012). I am an illegal alien on my own land. New York Review of Books, June 28.

Steves, R. (2011, November 18). The security fence, the anti-terrorism barrier, the wall. Huffington Post. Retrieved October 3, 2016, from http://www.huffingtonpost.com/rick-steves/the-security-fence-the-an_b_4296601.html

Times of Israel Staff. (2016, May 9). In Israel, most Jews don't see West Bank rule as “occupation”, most Arabs do. Retrieved October 2, 2016, from http://www.timesofisrael.com/in-israel-jews-dont- see-west-bank-rule-as-occupation-but-arabs-do/\# 
Vexler, M. (2012a). Visualizing ethnic cleansing. +972 Magazine. Retrieved September 30, 2016, from http://972mag.com/visualizing-occupation-ethnic-cleansing/43860/

Vexler, M. (2012b). Visualizing occupation: The distribution of water. +972 Magazine. Retrieved September 30, 2016, from http://972mag.com/visualizing-occupation-distribution-of-water/49925/

Winer, S. (2015, November 11). Shin Bet: Hopelessness fueling recent Palestinian attacks. The Times of Israel. Retrieved October 3, 2016, from http://www.timesofisrael.com/shin-bet-hopelessness-fueling-recent-palestinian-attacks/

Ziri, D. (2013, February 4). Textbooks show both sides to blame for enmity. Jerusalem Post. Retrieved October 7, 2016, from http://www.jpost.com/printarticle.aspx?id=302102\# 